\title{
Pardon Me!
}

Drime Minister Stephen Harper's omnibus crime bill, the Safe Streets and Communities Act (Bill C-10), altered Canada's pardoning practices to the detriment of Canadians. The Government of Canada's new prohibitive restrictions to the Criminal Records Act places a pardon out of reach for an increasing number of people. The restrictions added to the Criminal Records Act include: increasing the length of time required before a person may apply for a pardon (up to 10 years for some applicants); complete exclusion from the process for those applicants with more than three indictable offence convictions, no matter the circumstances of the crimes, how long ago they took place or the kinds of changes the person has made in his or her life since their conviction; utter disqualification of those convicted of child sex offences; and the Parole Board of Canada must be satisfied that the application will not bring the administration of justice into disrepute (Greenspan and Martin, 2014).

It may prove helpful to run quickly through the genesis of what a pardon looked like at an early time in our colonial history and what it has devolved into today. At one time in Canada, a person might have received Victorian mercy from Her Majesty the Queen in the form of a pardon. Under the old law, referred to as a true pardon granted by Her Majesty's Royal Prerogative of Mercy, a convicted person's criminal record was expunged. Anyone who received mercy from the Queen could lawfully deny having ever had a criminal record if they were asked. Today, the definition of a pardon is quite different from its merciful beginning.

In order to have earned a pardon under the old law, the criminalized would have completed the terms of their sentences, which would have included parole for many, remained crime-free for at least five years for indictable convictions and three years for summary convictions, and have been assessed as no longer presenting a risk to public safety (Greenspan and Martin, 2011). Earning a pardon indicates that the individual has become a sustained, taxpaying, contributing member of society. It means that our Canadian correctional system worked effectively in its efforts not only to promote rehabilitation, but also to provide meaningful and lasting pro-social changes.

A pardon under the modern Criminal Records Act is no more than keeping the record of conviction separate and apart from other criminal records. In other words, the conviction is sequestered from sight. A virtual red line is drawn through the conviction on file. Certain government 
agencies, for a variety of reasons and after obtaining permission, may review the sequestered files. One can no longer deny that they were convicted. This contemporary pardon is referred to as an administrative pardon; administrative pardons cleanse the person of the stain of their conviction from what might be called casual sight (Greenspan and Martin, 2014). It means, for example, that a person could apply for and receive a travel visa to a foreign country or consent to most criminal record checks for the purposes of employment without worrying about past indiscretions, but one could not expect to pass a criminal records check if he or she tried to enlist in the Armed Forces or if one applied for an elementary school bus driver position. This is the pardoning process that Bill C-10 (Safe Streets and Communities Act) orphaned from what was long held as a pinnacle of social forgiveness by those who sought its recognition and reward.

Prime Minister Harper and other right-wing thinkers also did away with the word "pardon" when they orphaned the Criminal Records Act from what it was before January 2012 to the poor stepchild that it is now. What was once referred to as a pardon is now called a record suspension. If a person is granted a record suspension, which includes such abstract considerations as ensuring the application will not bring the administration of justice into disrepute, the conviction is suspended from casual sight from low-level Canadian Police Intelligent Computer (CPIC) checks. This new criterion would seem to place public perception above the statues of law and fundamental justice. Lawmakers should revise laws to make them more just and to reflect Canadian values, not when they have surrendered to 'common sense', which seems to be the case here.

The Canadian Bar Association (2011) called the revisions to the Criminal Records Act both unnecessary and counterproductive. According to the Parole Board of Canada (2014, n.p.), "Since 1970, more than 460,000 Canadians have received pardons and record suspensions. 96 percent of these are still in force, indicating that the vast majority of pardon/record suspension recipients remain crime-free in the community". Pardons and record suspensions remain in effect until a person commits another crime. The fact that 96 percent of all granted pardons are still in effect today would seem to be undisputable proof that the Criminal Records Act accomplished what its pre-Bill C-10 authors intended. Given the government's new and legislated stance on public perception and not bringing the administration of justice into disrepute, one wonders why the Conservative government has 
not touted successful pardons from the highest mountain peak. Sadly, rather than support those people who turned their lives around and who earned a record suspension, the government questioned the efficacy of the Criminal Records Act triumphs.

According to Statistics Canada, approximately 97 percent of Canadians who applied for a pardon under the old Act received it (Parole Board of Canada, 2014). When Prime Minister Harper reported this statistic, he did so in a manner that questioned the integrity of the National Parole Board of Canada office, as though the applicants had not deserved the pardons they received. If 97 percent of applicants met the legislated criteria, we should applaud their hard work and support their endeavours, not cast doubt upon the competence of civil servants who appraised applicant suitability. A 97 percent success rate is an A+ where I went to school.

Pardons, or record suspensions in the new vernacular, allow individuals to access better paying jobs that in turn permit them to offer their families an improved lifestyle. It is also a symbol of social forgiveness, a milestone that helps reformed, law-abiding citizens to put their troubled past behind them. Prime Minister Harper's fear-mongering reforms to the Criminal Records Act is but one more barrier to positive social reintegration that is akin to a great big boot that pushes one back down into the muck from which a person struggled to remove themselves. Prime Minister Harper has perhaps forgotten that many people who have had a brush with the law have also been exposed to physical abuse, sexual abuse, and emotional abuse as children, and as an adult suffered from a drug or alcohol addiction. Keep your big boot to yourself, Mr. Harper, and extend a helping hand lest you send an ideological message that a segment of our population is unsalvageable. Rather than motivate positive change, the Bill C-10 legislation makes it more difficult for Canadians to repair their lives.

According to a report in the Globe and Mail, "statistics released to The Canadian Press under the federal access-to-information law show 15,871 applicants between March 2012 and this past December, down more than 40 per cent on an annualized basis compared with 2009-10" (Bronskill and Cheadle, 2013). It means that our sons and daughters, our brothers and sisters, will forever be second-rate citizens. So much for the family values Prime Minister Harper and the Conservative Party preach at the public pulpit. The sad and sorry fact is that the Conservative Party's gettough-on-crime agenda elicits public fear and it hopes to earn votes on 
Election Day. The changes to the pardon process do not get tough on crime, it gets tough on people who are no longer committing criminal acts, but the government does not seem worried about this public perception. They are more concerned with being perceived as making inroads toward reducing crime without ever having done anything substantive and they do not mind if certain Canadians suffer to achieve this end.

Unbeknownst to many Canadians, violent crime has been declining for two decades. As of today, incidents of violent crime in Canada are at their lowest since the mid-1960s, yet many right-wing conservative politicians would have Canadians believe that criminals are running amuck through our streets and communities and that they alone are single-handedly championing safer streets by restricting access to a record suspension. While Canadians may want increasingly safer streets, how does getting tough on people who have reformed themselves achieve that goal? How does getting tough on people who have lived crime-free for years keep my family safe?

The alterations to the Criminal Records Act conflict with the Correctional Service of Canada's mission statement that states, as a core value, "We recognize the offender has the potential to live as a law-abiding citizen" (Report of the Working Group on Human Rights, 1999). Prime Minister Harper knows all too well that pardoned, law-abiding citizens pay taxes, but he also realizes that the few hundred people that receive pardons each year are not a statistical voting threat. Former prisoners represent a segment of the population that the federal government can punish with impunity while appearing to champion justice to the rest of the people. It is unlikely that special interest groups will risk the negative media coverage and come to the aid of ex-criminals, ergo Mr. Harper and his backbenchers are free to play King of the Mountain with the lives of the underprivileged.

Hidden behind the smoke and mirrors of get-tough-on-crime rhetoric, the Conservative Party's stance gets tough on rehabilitated criminals while doing nothing to prevent unlawful behaviour. If judged solely by the modifications to the Criminal Records Act, Bill C-10, the Safe Streets and Communities Act, promotes exclusion while adding to a growing number of underprivileged social outcasts. This would seem to elevate the likelihood of crime, not reduce it. While Canadians were distracted by the boisterous 'dog and pony' show, the Harper government chipped another chunk of compassion out of our approach to evidence-based justice. Unless Canadians stand up true, north, strong, and free, Prime Minister Harper and 
his right-wing Conservatives will strip Canada of this aspect of its national identity. The words "pardon me" will disappear from our language unless we stop stopping inaction against unreasonable government practices.

\section{REFERENCES}

Bronskill, Jim and Bruce Cheadle (2013) "New rules make for massive drop in pardons", Globe and Mail - January 11. Retrieved from http://www.theglobeandmail.com/ news/world/new-rules-make-for-massive-drop-in-pardons/article7217712

Canadian Bar Association (2011) Submission on Bill C-10 Safe Streets and Communities Act. Retrieved from http://www.cba.org/cba/submissions/PDF/11-45-eng.pdf.

Greenspan, Edward L. and John C. Martin (2014) Martin's Related Criminal Statutes 2013-2014. Retrieved from http://www.canadalawbook.ca.

Greenspan, Edward L. and John C. Martin (2011) Martin's Related Criminal Statutes 2010-2011. Retrieved from http://www.canadalawbook.ca.

Parole Board of Canada (2014) PBC Quickfacts. Retrieved from http://www.pbc-clcc. gc.ca/infocntr/factsh/parole_stats-eng.shtml.

Report of the Working Group on Human Rights (1999) Human Rights in Community Corrections. Retrieved from http://www.csc-scc.gc.ca/005/007/rights/wgroup/toceeng.shtml.

\section{ABOUT THE AUTHOR}

Jeremy Fry is a 53 year-old man who was sentenced to life for killing a man in the mid-1980's. Jeremy is currently on parole and working as an electrician while he pursues his goal of becoming an author. Kalen's Sword, one of his earlier novels, was published by TallTails Press in 2004. His latest work, Never Look Back, is under review by Ekstasis, a publishing company out of British Columbia. 